\title{
SYNTHESIS, CHARACTERIZATION AND ANTIBACTERIAL ACTIVITY OF NEW BRIDGED AND MACROCYCLIC SCHIFF BASES
}

\author{
Ahmad Falah \\ Department of chemistry, Faculty of science, University of Damascus, Syria
}

\begin{abstract}
In this work we focused on the synthesis of new Open Schiff bases were prepared by condensation of salicylaldehyde with both 4,4'-diaminodiphenyl methane,4,4'-diamino diphenyl sulphide,and condensation of O-vanilin with diethyl ester of terephthalic acid respectively, and also were prepared New Macrocyclic Schiff Bases by condensation of 1,6-dibromohexane with thiocarbohydrazid. The Schiff base were checked by different spectral techniques (LC-MS, ${ }^{1} \mathrm{H}-\mathrm{NMR}$, IR). The Schiff bases have been screened for their antibacterial activity, where compound (II) showed promising results against gram positive and gram negative bacteria.
\end{abstract}

Keywords: Open Schiff base, Macrocyclic, Salicylaldehyde, Spectral Technique, Antibacterial Activity.

\section{INTRODUCTION}

Azomethine group $(-\mathrm{C}=\mathrm{N}-)$ containing compounds typically known as Schiff bases have been synthesized by the condensation of primary amines with active carbonyls. Schiff bases form a significant class of compounds in medicinal and pharmaceutical chemistry with several antibacterial applications that include antibacterial, [1-6] antifungal [3-6] and antitumor activity [7-8]. They have been studied extensively as a class of ligands [9-11] and are known to coordinate with metal ions through the azomethine nitrogen atom. Schiff base complexes play a vital role in designing metal complexes related to synthetic natural oxygen carriers [12]. Metal complexes make these compounds effective as stereospecific catalysts towards oxidation, reduction, hydrolysis, antibacterial activity and other transformations of organic and inorganic chemistry [13]. In organic compounds the presence of $-\mathrm{C}=\mathrm{N}-$ along with other functional groups form more stable complexes compared to compounds with only $-\mathrm{C}=\mathrm{N}-$ coordinating moiety. Similarly coumarin derivatives have a great interest because of their role in natural and synthetic organic chemistry. Many products which contain a coumarin subunit exhibit antibacterial activity such as molluscicides, [14] anthelmintic, hypnotic, insecticidal [15] activity and some are serving as anticoagulant agents [16] and fluorescent brighteners. So coumarins containing a Schiff base are expected to have enhanced antitumor and other antibacterial activities. It is well established that the antibacterial activity associated with the hydrazone compounds attributed to the presence of the active pharmacophore (-CONH-N=C-). Hence many hydrazone compounds containing this active moiety showed good anticancer bioactivities according to the literature [17]. Hence, in this paper, we are reporting the synthesis of New open and Macrocyclic Schiff bases from 
condensation of Salicylaldehyde with 4, 4'diamino diphenyl methane, 4, 4'diaminodiphenyl sulphide, and their characterization by spectral data such as IR, ${ }^{1} \mathrm{H}$ NMR and Mass spectra was studied. Their antimicrobial activity was also evaluated [18].

\section{EXPERIMENTAL}

\subsection{MATERIALS AND METHOD}

Ethanol, dimethyl formamide, salicylealdehyde, 1, 6-dibromohexane, diethylether, 4, 4'-diamino diphenyl methane, 4,4'-diamino diphenyl sulphide, hydrazine hydrate, diethyl ester of terephthalic acid, $\mathrm{K}_{2} \mathrm{CO}_{3}$, Nutrient agar, Filter paper discs (Whatman No.1 filter paper, $5 \mathrm{~mm}$ diameter). All materials obtained from Sigma Aldrich Company.

IR spectra was recorded on Jusco 300 FT-IR Spectrometer using compressed $\mathrm{KBr}$ discs. Mass spectra of the ligand were measured on a micro mass Quattro LC-MS/MS Spectrometer. ${ }^{1} \mathrm{H}-\quad$ NMR spectra were recorded at ambient Broker DT-400 Spectrometer using $\mathrm{CDCl}_{3}$ with DMSO$\mathrm{DMF}$ as the internal standard.

2.2. SYNTHESIS OF $3, \quad$ 13-DIAZA-4, 12 DIPHENYLMETHANE, $\left(2^{\prime}, 2^{\prime}\right.$-DIHYDROXY-PHENYL $) 2$, 14-DECA-DIENE. (I)
The compound was prepared by a usual Schiff s base condensation in methanol $(50 \mathrm{~mL})$ of salicylaldehyde (10 mmol,1.22 g) with bridging diamine (4,4'-diamino diphenylmethane, $5 \mathrm{mmol}, 1.00 \mathrm{~g})$. The solutions were stirred and refluxed for 6h.Gold Yellow precipitates were filtered,washed by a small amount of methanol and dried in vacuum . Yield:(87\%),m.p $\left.>300 \quad{ }^{0} \mathrm{C}\right), \quad$ Empirical formula: $\left(\mathrm{C}_{27} \mathrm{H}_{22} \mathrm{~N}_{2} \mathrm{O}_{2}\right)$, M.Wt: (406).

Mass spectra $(\mathrm{m} / \mathrm{z}): 406[\mathrm{~L}]^{+}$.

The Elemental analyses :C, 78.76; H, 5.42; N, 6.89; O, 7.87. found, C, 78.79; H, 5.39; N, 6.87; O, 7.84 .

IR $(\mathrm{KBr}$ disk $): 1637.5 \mathrm{~cm}^{-1} \quad(\mathrm{HC}=\mathrm{N})$, $1284.6 \mathrm{~cm}^{-1}$ (C-O), $2850.8 \mathrm{~cm}^{-1}$ (C-H alkanes), $1497.2 \mathrm{~cm}^{-1}(\mathrm{C}=\mathrm{C}), 3236.4 \mathrm{~cm}^{-1}$ (C-H Ar), $3415-3551.7 \mathrm{~cm}^{-1}(-\mathrm{OH})$.

1HNMR(400Hz; d6-DMSO) $\delta 13.33(2 \mathrm{H}, \mathrm{s}$, $\mathrm{OH}) ., 6.660-7.422(\mathrm{~m}, 16 \mathrm{H}, \mathrm{Ar}), 3.926-$ $4.068(2 \mathrm{H},-\mathrm{CH} 2-) 8.65(\mathrm{~s}, 2 \mathrm{H}, \mathrm{CH}=\mathrm{N})$.

2.3. SYNTHESIS OF 3, 13-DIAZA-4, 12 DIPHENYL SULPHIDE, (2', 2'-DIHYDROXY PHENYL)2, 14-DECADIENE (II).

A hot ethanolic solution $(50 \mathrm{ml})$ of salicylaldehyde $(4.88 \mathrm{~g}, 0.04 \mathrm{~mol})$ was added to a hot ethanolic solution $(50 \mathrm{ml})$ of diaminodiphenyl sulphide $(4.32 \mathrm{~g}, 0.02 \mathrm{~mol})$ and the reaction mixture was refluxed for $5 \mathrm{~h}$. A brown product was formed.<smiles>Nc1ccc([CH]c2ccc(N)cc2)cc1</smiles><smiles>C=CCN</smiles><smiles>Oc1ccccc1C=Nc1ccc(Cc2ccc(C=Nc3ccccc3O)cc2)cc1</smiles><smiles>Oc1ccccc1C=Nc1ccc(Sc2ccc(N=Cc3ccccc3O)cc2)cc1</smiles> 

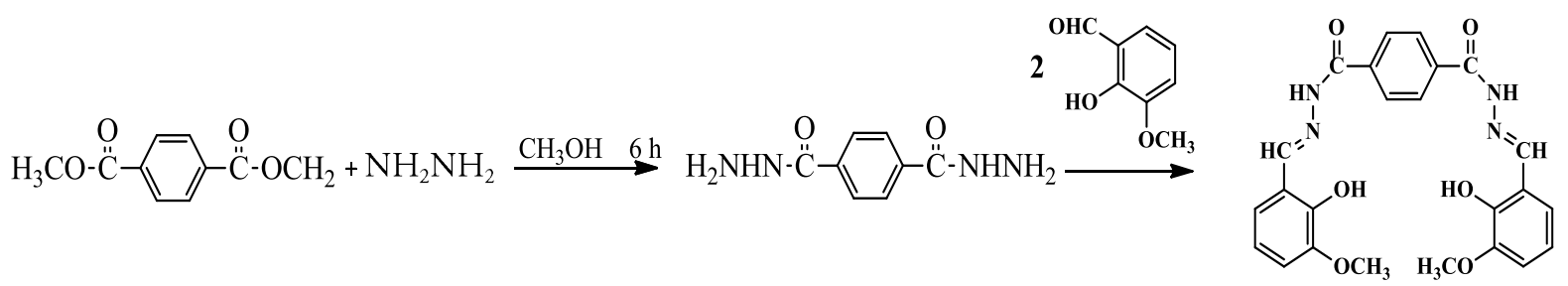

(III)

It was filtered, washed with ethanol, diethyl ether and subsequently dried over anhydrous $\mathrm{CaCl}_{2}$ in desiccators. The Schiff base ligand is soluble in some organic solvents. (dimethylformamide and dimethylsulfoxide). Yield : $(75 \%), \quad$ m.p $\left.>300^{\circ} \mathrm{C}\right), \quad$ Empirical formula: $\left(\mathrm{C}_{26} \mathrm{H}_{20} \mathrm{~N}_{2} \mathrm{O}_{2} \mathrm{~S}\right)$, M.Wt: (424).

Mass $\operatorname{spectrum}(\mathrm{m} / \mathrm{z}): 424[\mathrm{~L}]^{+}$

The Elemental analyses : C, 73.56; H, 4.74; $\mathrm{N}, 6.57 ;$ S, 7.56., found, C, 73.58; H, 4.75; N, 6.56; S , 7.61.

IR $(\mathrm{KBr} \quad$ disk $): 1616.4 \quad \mathrm{~cm}^{-1} \quad(\mathrm{C}=\mathrm{N}) \quad$, $1284.2 \mathrm{~cm}^{-1}$ (C-O), $1456.3-1496.7 \mathrm{~cm}^{-1}(\mathrm{C}=\mathrm{C})$, $3052 \mathrm{~cm}^{-1}(\mathrm{C}-\mathrm{H} \quad \mathrm{Ar}), \quad 3414.8-3550.7 \mathrm{~cm}^{-1}$ $(-\mathrm{OH})$.

${ }^{1} \mathrm{H}-\mathrm{NMR} \quad\left(\mathrm{DMSO}-\mathrm{d}_{6}\right.$ vs.TMS) $\delta=13.147$ $(\mathrm{s}, 2 \mathrm{H}, \mathrm{OH}), \quad 6.960-7.451 \quad(\mathrm{~m}, \quad 16 \mathrm{H}, \mathrm{Ar})$, 8.617-8.657 (s,2H,CH=N).

2.4. SYNTHESIS OF 3, 12-DIAZA-4, 11-DICARBONYL PHENYL DIHYDRAZIDE, (2', 2'-DIHYDROXY, 3', 3'METHOXY PHENYL) 2, 14-DECADIENE. (III)

\section{Synthesis of dihydrazide of terephthalic acid}

A mixture of dimethyl ester of terephthalic acid $(2.22 \mathrm{~g})$ and hydrazine hydrate (98\% $2 \mathrm{cc}$ ) in ethanol was refluxed for $4-5 \mathrm{~h}$. The reaction mixture was allowed to cool to room temperature, then the cooled solution was poured onto ice cold water. The dihydrazide of terephthalic acid thus obtained was filtered and recrystallized from ethanol [19].

Yield: $(88 \%)$, m.p $\left.>300^{\circ} \mathrm{C}\right)$, Empirical formula: $\left(\mathrm{C}_{8} \mathrm{H}_{10} \mathrm{~N}_{4} \mathrm{O}_{2}\right)$, M.Wt: (194).

Mass spectrum $(\mathrm{m} / \mathrm{z}): 194[\mathrm{~L}]^{+}$

IR( $\mathrm{KBr}$ disk): $3329.50 \mathrm{~cm}^{-1}\left(\mathrm{NH}_{2}\right), 3210$, 90(NH), 3036-2961 cm $\mathrm{cm}^{-1}$, (Ar-CH), 1698,
$1628 \mathrm{~cm}^{-1}(\mathrm{C}=\mathrm{O}), \quad 1428.60 \mathrm{~cm}^{-1} \quad(\mathrm{C}=\mathrm{C})$, $765.6 \mathrm{~cm}^{-1}$ (substituted benzene).

\section{Synthesis of ligand(III)}

o-vanilin $(2 \mathrm{mmol})$ in ethanol $(50 \mathrm{~mL})$ was added to an ethanolic solution of 1,4dicarbonyl phenyl dihydrazide $(1 \mathrm{mmol}$, $30 \mathrm{~mL}$ ) containing a few drops of concentrated $\mathrm{HCl}$. The reaction mixture was refluxed for $3 \mathrm{~h}$. The mixture was cooled to room temperature. The solid product was formed filtered and washed with cold ethanol and dried under vacuum. Yield : (65\%) , m.p $\left.>300{ }^{0} \mathrm{C}\right) \quad$, Empirical formula: $\left(\mathrm{C}_{24} \mathrm{H}_{22} \mathrm{~N}_{4} \mathrm{O}_{6}\right)$, M.Wt:(462).

Mass $\operatorname{spectrum}(\mathrm{m} / \mathrm{z}): 462[\mathrm{~L}]^{+}$

The Elemental analyses :C,62.34; H, 4.77; N, 12.10; O, 20.75. found., C,62.41; H, 4.78; N, 12.12; O, 20.79 .

IR $(\mathrm{KBr}$ disk $): 1601.9 \mathrm{~cm}^{-1} \quad(\mathrm{C}=\mathrm{N})$, $1645.5 \mathrm{~cm}^{-1}(\mathrm{C}=\mathrm{O}), 1285.7 \mathrm{~cm}^{-1}$ (C-O), 2950 $\mathrm{cm}^{-1}$ (C-H alkanes), $3000 \mathrm{~cm}^{-1}$ (C-H Ar), $1451.5-1515.7 \mathrm{~cm}^{-1}(\mathrm{C}=\mathrm{C}), 3230.8 \mathrm{~cm}^{-1} \quad(-\mathrm{C}-$ $\mathrm{NH}-), 3432.5 \mathrm{~cm}^{-1}(-\mathrm{OH})$.

${ }^{1} \mathrm{H}-\mathrm{NMR}$ (DMSO-d $\mathrm{d}_{6}$ vs.TMS) $\delta=13.327$ (s,2H,OH), 7.285-8.285 (m,12H,Ar), 3.7133.763 (s, 6H, O-CH $\left.{ }_{3}\right) 8.601$ (s, 2H, C=NH), $9.845(\mathrm{NH}-\mathrm{C}=\mathrm{O})$.

\subsection{SYNTHESIS OF 1,16-DIAZA-(3,4;13,14- DIBENZO)-17,19- THIOCARBOHYDRAZIDE - 5,8,11,14-TETRA-OXACYCLO HEPTACOSINE-1,15- DIENE(IV)}

Synthesis of 1,6- bis (2- formyl phenel) hexane .

To a stirred solution of salicylaldehyde (2.44 $\mathrm{g}-0.02 \mathrm{~mol})$ and $\mathrm{K}_{2} \mathrm{CO}_{3}(1.38 \mathrm{~g}-0.01 \mathrm{~mol})$ in DMF (50ml) 1,6-dibromohexane (1.22 g $0.01 \mathrm{~mol})$ in $\mathrm{DMF}(10 \mathrm{ml})$ was added drop wise, 


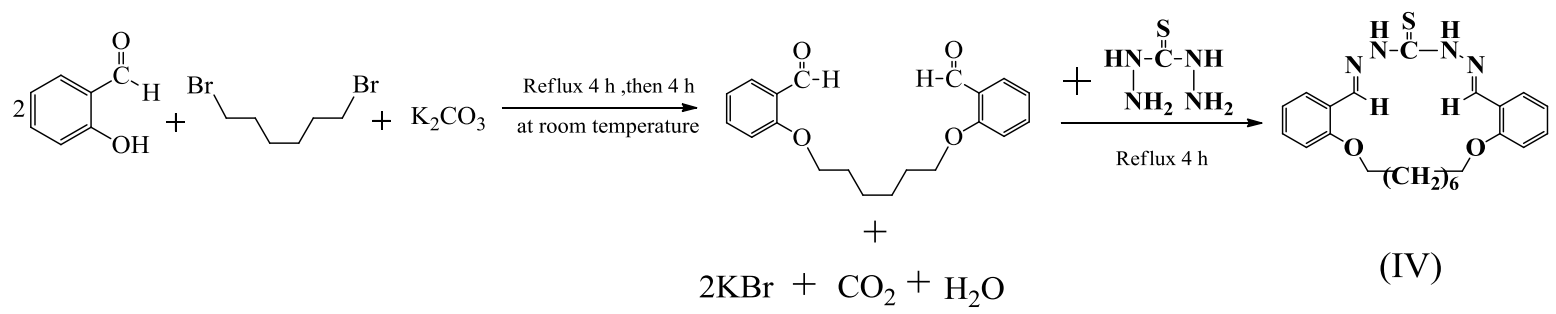

the reaction was continued with stirring for $10 \mathrm{~h}$ at $150-155^{\circ} \mathrm{C}$ and then $5 \mathrm{~h}$ at room temperature [20]. After the addition was completed, $20 \mathrm{ml}$ distilled water was added it was put in a refrigerator, $1 \mathrm{~h}$ later the precipitate was filtered washed by $50 \mathrm{ml}$ water dried in air, recrystallized from ethanol.Yield:(88\%),m.p $\left.=75{ }^{\circ} \mathrm{C}\right)$, Empirical formula: $\left(\mathrm{C}_{20} \mathrm{H}_{22} \mathrm{O}_{4}\right)$, M.Wt:(326).

Mass spectra $(\mathrm{m} / \mathrm{z}): 326[\mathrm{~L}]^{+}$

$\mathrm{IR}(\mathrm{KBr}$ disk $)$ : $3071,3038 \mathrm{~cm}^{-1}(\mathrm{Ar}-\mathrm{CH})$, $2949-2853 \mathrm{~cm}^{-1}($ Alk. $-\mathrm{CH}), 1683 \mathrm{~cm}^{-1}(\mathrm{C}=\mathrm{O})$, $1485-1455 \mathrm{~cm}^{-1}$ (Ar-C=C), 1288.22-1246.75 $\mathrm{cm}^{-1}(\mathrm{Ar}-\mathrm{O}), 1188-1036 \mathrm{~cm}^{-1}$ (R-O) ,757.89 $\mathrm{cm}^{-1}$ (substituted benzene).

\section{Synthesis of the macrocyclic Schiff bases(IV)}

The macrocyclic ligand(IV-B) was prepared by dropwise addition of a solution of the thiocarbohydrazide $(2 \mathrm{mmol})$ in methanol $(40$ $\mathrm{ml})$ to a stirred solution of 1,6-bis(2formylphenyl) hexane $(2 \mathrm{mmol})$ in methanol $(60 \mathrm{ml})$. After the addition was completed, stirring was continued for $4 \mathrm{~h}$. yellow colored precipitate was filtered and washed with methanol.Yield:(65\%), m.p $>300^{\circ} \mathrm{C}$ ), Empirical formula: $\quad\left(\mathrm{C}_{21} \mathrm{H}_{24} \mathrm{~N}_{4} \mathrm{O}_{2} \mathrm{~S}\right)$, M.Wt:(396).

Mass spectra $(\mathrm{m} / \mathrm{z}): 396[\mathrm{~L}]^{+}$

The Elemental analyses : C, 63.58; H, 6.11; N, 14.11; O, 8.04;S, 8.08. found., C, 63.54; $\mathrm{H}, 6.10 ; \mathrm{N}, 14.11 ; \mathrm{O}, 8.02 ; \mathrm{S}, 8.03$

IR (KBr disk): $1637.2 \mathrm{~cm}^{-1}(\mathrm{C}=\mathrm{N}), 1616.8 \mathrm{~cm}^{-1}$ $(\mathrm{C}=\mathrm{S}), 1245.2 \mathrm{~cm}^{-1}$ (C-O), 1106.5-1160.5(RO), $2869 \mathrm{~cm}^{-1}$ (C-H alkanes), $1455.3-1486.2$ $\mathrm{cm}^{-1}(\mathrm{C}=\mathrm{C}), 2939.3 \mathrm{~cm}^{-1}(\mathrm{C}-\mathrm{H}$ Ar$), 3414.3-$ $3477 \mathrm{~cm}^{-1}\left(\mathrm{H}_{2} \mathrm{O}\right), 3236.8$ (C-NH-).
${ }^{1} \mathrm{H}-\mathrm{NMR}\left(\mathrm{DMSOd}_{6}\right.$ vs.TMS) $\delta=1.9082 .103$ $\left(8 \mathrm{H}, \mathrm{CH}_{2} \mathrm{CH}_{2}\right), 6.987-7.663(\mathrm{~m}, 8 \mathrm{H}, \mathrm{Ar}-\mathrm{H})$, 3.262-3.491 (4H,O-CH$) ~ 8.3(2 \mathrm{H}, \mathrm{HC}=\mathrm{N})$, $2.954(\mathrm{NH}-\mathrm{N})$.

\subsection{ANTIBACTERIAL ACTIVITY}

The compounds were tested for their antimicrobial activity against four speices of bacteria (klebcella، Escherichia coli، Staphylococcus aureus ' Salmonella typhi) using filter paper disc method [21].The screened compounds were dissolved individually in DMSO(dimethyl sulfoxide) in order to make up a solution of $1000 \mu \mathrm{g} / \mathrm{ml}$ concentration for each of these compounds. Filter paper discs (Whitman No.1 filter paper, $5 \mathrm{~mm}$ diameter) were saturated with the solution of these compounds. The discs were placed on the surface of solidified Nutrient agar dishes seeded by the tested bacteria. The diameters of inhibition zones $(\mathrm{mm})$ were measured at the end of an incubation period,which was $24 \mathrm{~h}$ at $37 \mathrm{C}$ for bacteria. Discs saturated with DMSO are used as solvent control. Ampicillin $25 \mu \mathrm{g} / \mathrm{ml}$ was used as reference substance for bacteria [22].

\section{RESULT AND DISCUSSION}

The prepared organic Ligands (I,II, III,IV) were soluble in DMF,DMSO and partially soluble in acetone, chloroform, carbon tetra chloride. All the ligands are characterized by LC-MS (Figures 1,4,7,10),IR, ${ }^{1} \mathrm{H}-\mathrm{NMR}$ spectra, which help in elucidating their empirical formula (Table 1 ). 
TABLE 1: COLOR,MOLECULAR WEIGHT,MELTING POINT OF (I,II,III,IV).

\begin{tabular}{|l|l|l|l|}
\hline Ligand & Color & M.Wt & $\begin{array}{l}\text { Melting point } \\
{ }^{\circ} \mathrm{C}\end{array}$ \\
\hline I & Gold Yellow & 406 & $>300{ }^{\circ} \mathrm{C}$ dec. \\
\hline II & Brown & 424 & $>300{ }^{\circ} \mathrm{C}$ dec. \\
\hline III & Yellowish white & 462 & $>300{ }^{\circ} \mathrm{C} \mathrm{dec}$. \\
\hline IV & yellow & 396 & $>300^{\circ} \mathrm{C} \mathrm{dec}$. \\
\hline
\end{tabular}

ec $=$ decomposition

\subsection{IR SPECTRA}

IR Spectra of Schiff bases (I,II,III,IV) (Figures $1,3,5,7)$ are shown in table (2) the significant IR absorption bands. The four bands at $1637.5,1616.4,1601.9,1637.2 \mathrm{~cm}^{-1}$ are attributed to imine group $(-\mathrm{HC}=\mathrm{N}-)$ for (I,II,III,IV), respectively. The bands in the spectra at 1497.2, 1456.3-1496.7, 1451.51515.7 and $1455.3-1486.2$ is due to $(\mathrm{C}=\mathrm{C})$ of aromatic rings. The $\mathrm{v}(\mathrm{OH})$ stretching frequencies bands are observed at 3415$3551.7,3414.8-3550.7,3432.5 \mathrm{~cm}^{-1}$ for (I,II,III), respectively. Also, a strong $\mathrm{v}\left(\mathrm{H}_{2} \mathrm{O}\right)$ band of ligand (IV) at 3414-3477 about is observed because of hydrated water molecule. The IR spectra of (III,IV) show characteristic absorption bands at 3230.8 and $3236.8 \mathrm{~cm}^{-1}$ due to $\mathrm{v}(-\mathrm{NH}-)$ stretching vibrations, respectively. The bands which observed for all Ligands at 1284.6, 1284.2, 1285.7 and
$1245.2 \mathrm{~cm}^{-1}$ due to $\mathrm{v}(\mathrm{C}-\mathrm{O})$ vibration, while the bands at 2850.8,2950 and 2869-2939 $\mathrm{cm}^{-}$ ${ }^{1}$ are attributed to (C-H alkanes) for (I,III,IV) respectively . Also, the bands at 3236.4, 3052, 2939 and $3000 \mathrm{~cm}^{-1}$ about are attributed to (C-H Ar) for (I,II,IV,III) respectively.

\section{2. ${ }^{1}$ H-NMR SPECTRA}

The data of ${ }^{1} \mathrm{H}-\mathrm{NMR}$ Spectra of prepared compounds are shown in table (3). The ${ }^{1} \mathrm{H}$ NMR spectra of (I,II,III,IV) ligands in $\mathrm{d}_{6}$ DMSO (Figures 2,4,6,8) shows a singlet signal at $13.339,13.147$ and $13.327 \mathrm{ppm}$ assigned to the protons $\mathrm{OH}$ groups of the Ligands (I,II,III) respectively. The multiplet signals $\quad 6.660-7.422, \quad 6.960-7.451,7.285-$ 8.285 and 6.987-7.663 ppm are due to the aromatic protons for (I,II,III,IV) respectively. Also the signals at $8.65,8.617,8.601$ and $8.3 \mathrm{ppm}$ are assigned to the $2 \mathrm{H},(\mathrm{HC}=\mathrm{N})$ protons of the Ligands (I,II,III), respectively.

TABLE 3: ${ }^{1}$ HNMR SPECTRA OF THE PREPARED SCHIFF BASES 1-IV SPECTRA OF LIGANDS(I-IV)

\begin{tabular}{|l|l|l|l|}
\hline Ligand & $(\mathrm{s}, 2 \mathrm{H}, \mathrm{OH})$ & $(\mathrm{m}, \mathrm{H}, \mathrm{Ar})$ & $(\mathrm{s}, 2 \mathrm{H}, \mathrm{C}=\mathrm{NH})$ \\
\hline I & 13.339 & $6.660-7.422$ & 8.65 \\
\hline II & 13.147 & $6.960-7.451$ & 8.617 \\
\hline III & 13.327 & $7.285-8.285$ & 8.601 \\
\hline IV & - & $6.987-7.663$ & 8.3 \\
\hline
\end{tabular}

TABLE 2: IR SPECTRA OF LIGANDS(I,II,III-B,IV-B)

\begin{tabular}{|c|c|c|c|c|c|c|c|}
\hline Ligand & $\mathbf{v}(\mathrm{C}=\mathrm{N})$ & $\mathbf{v}(\mathrm{C}-\mathrm{O})$ & $\mathbf{v}(\mathrm{OH})$ & $\mathbf{v}(\mathrm{CH}-\mathrm{Ar})$ & $\mathbf{v}(\mathrm{NH})$ & $\mathbf{v}(\mathrm{CH}-\mathrm{Alka})$ & $\mathbf{v}(\mathrm{C}=\mathrm{O})$ \\
\hline I & 1637.5 & 1284.6 & $3415-3551.7$ & 3236.4 & - & 2850.8 & - \\
\hline II & 1616.4 & 1284.2 & $3414.8-3550.7$ & 3052 & - & - & - \\
\hline III & 1601.9 & 1285.7 & 3432.5 & 3000 & 3230.8 & 2950 & 1723.88 \\
\hline IV & 1637.2 & 1245.2 & - & 2939 & 3236.8 & 2869 & - \\
\hline
\end{tabular}


Yanbu Journal of Engineering and Science Vol. 5 (2012)

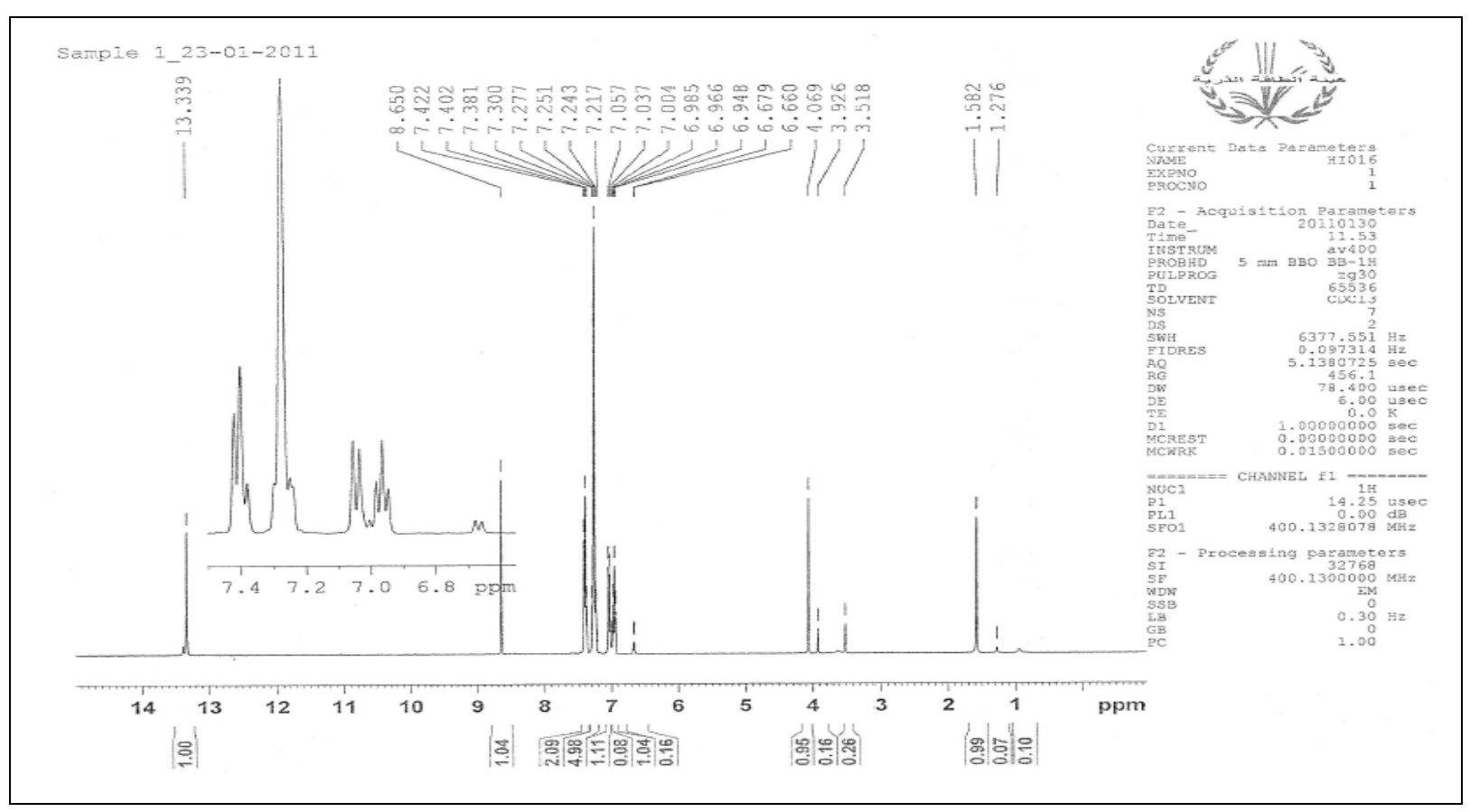

Fig.1. IR spectrum of Schiff base (I)

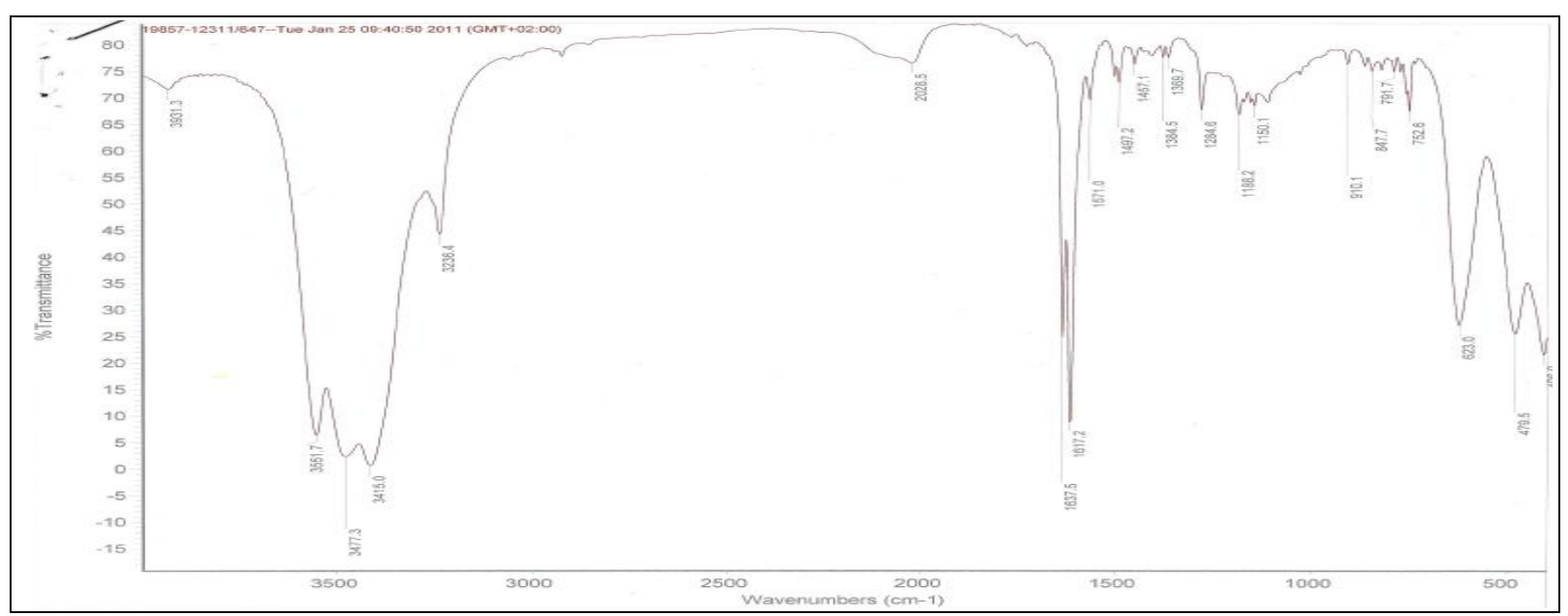

Fig. $2 .{ }^{1} \mathrm{H}$ NMR spectrum of Schiff base(I)

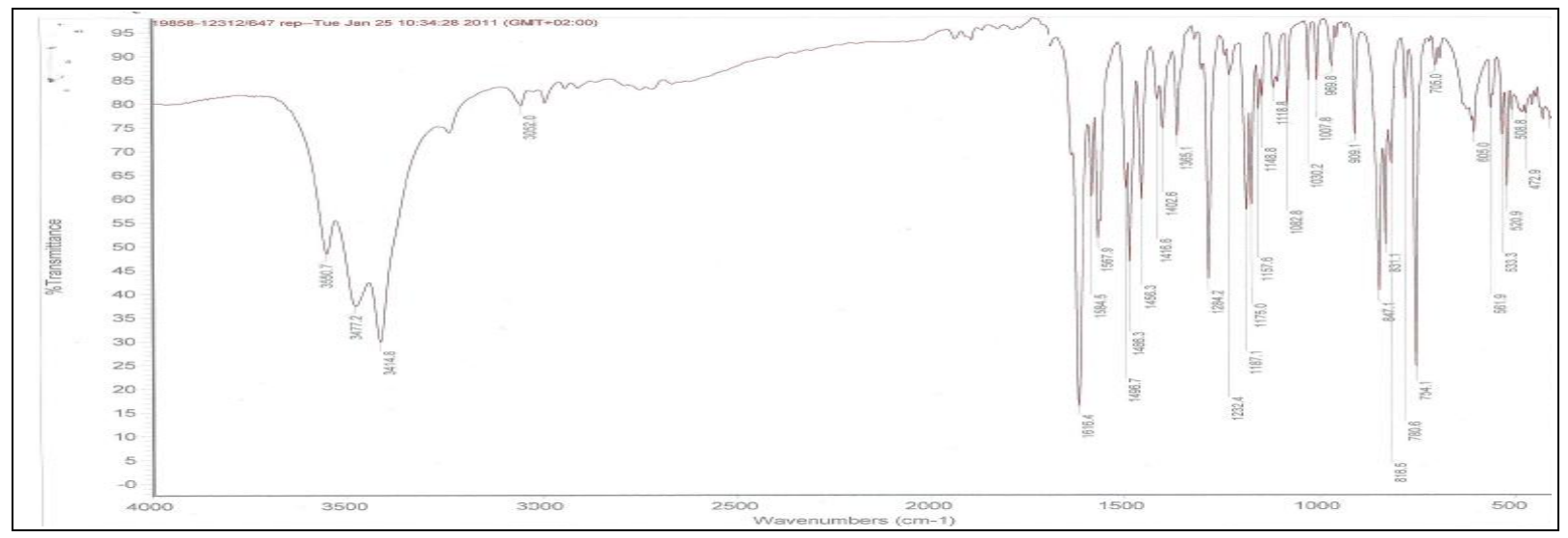

Fig.3. IR spectrum of Schiff base(II) 


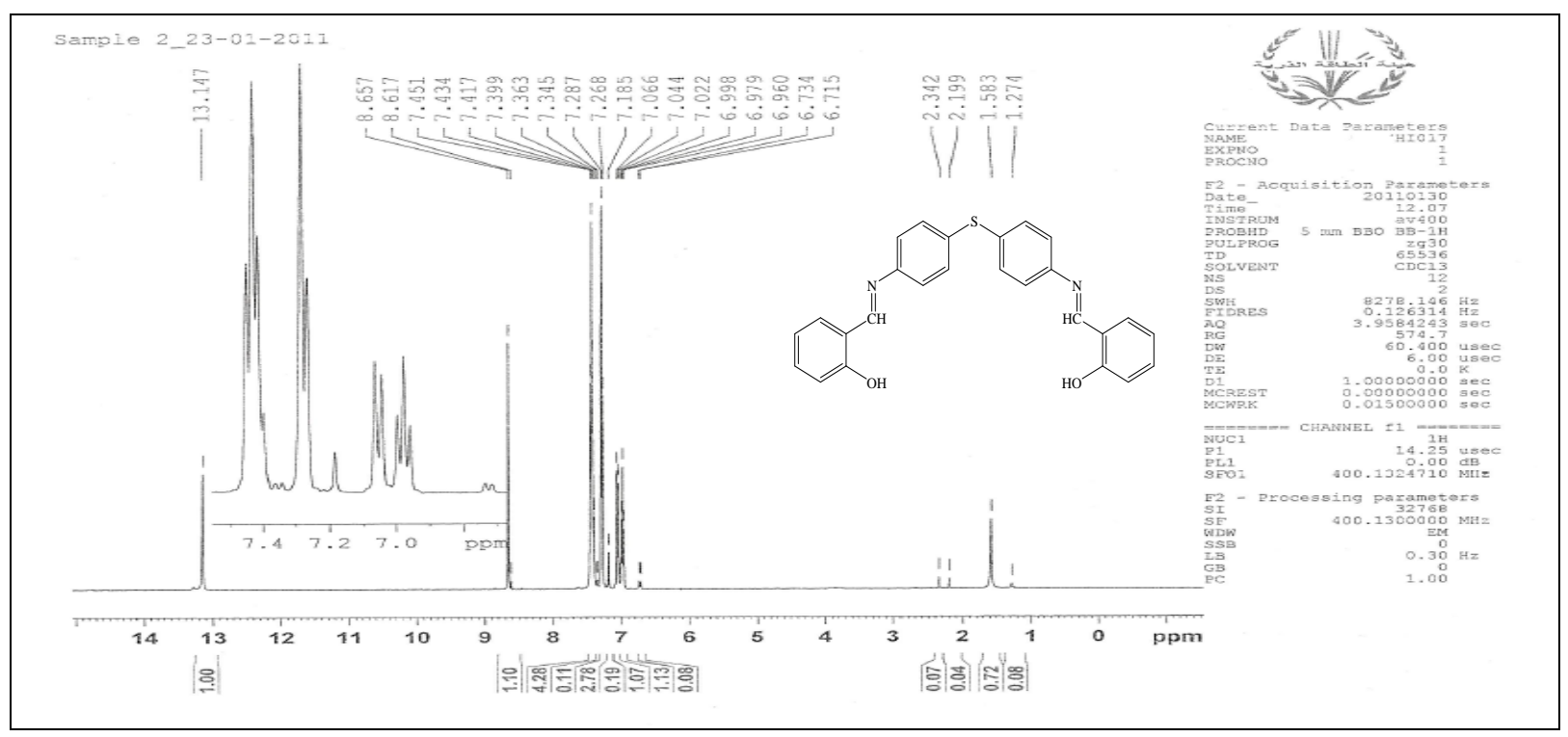

Fig.4. ${ }^{1} \mathrm{H}$ NMR spectrum of Schiff base(II)

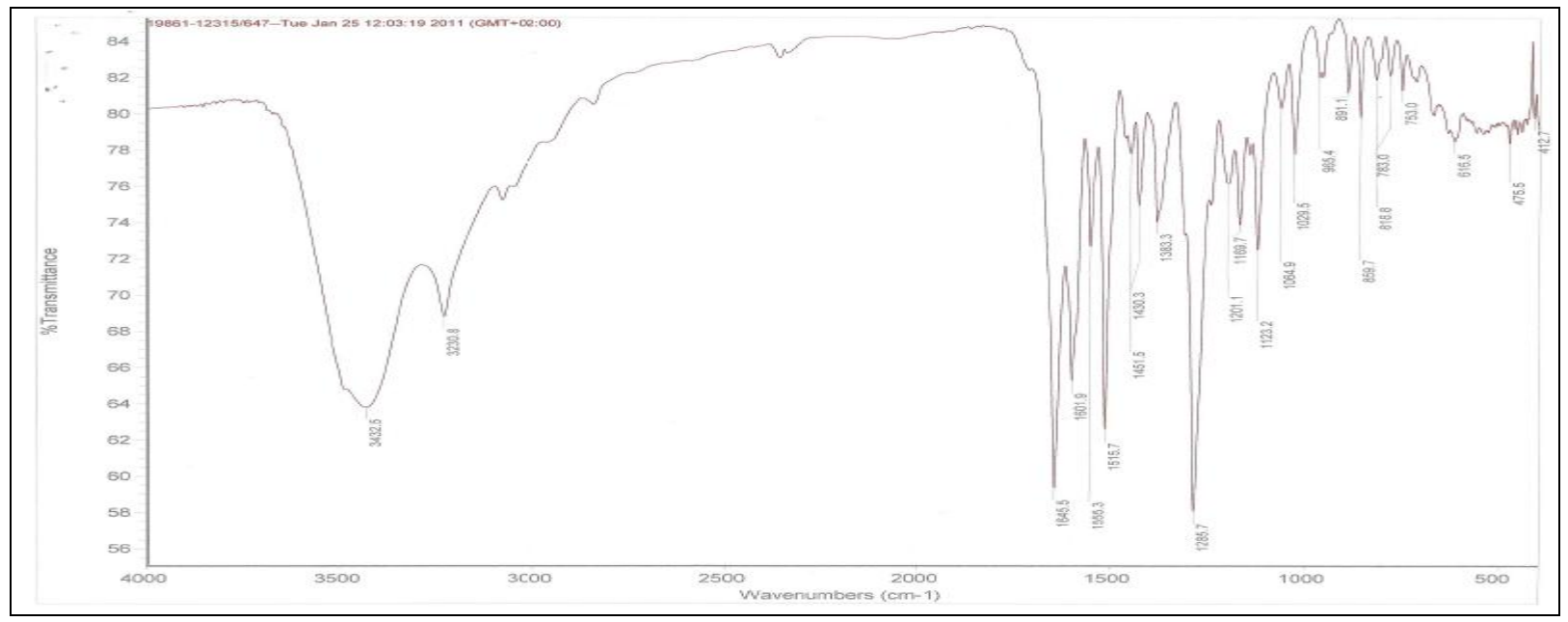

Fig.5. IR spectrum of Schiff base(III)

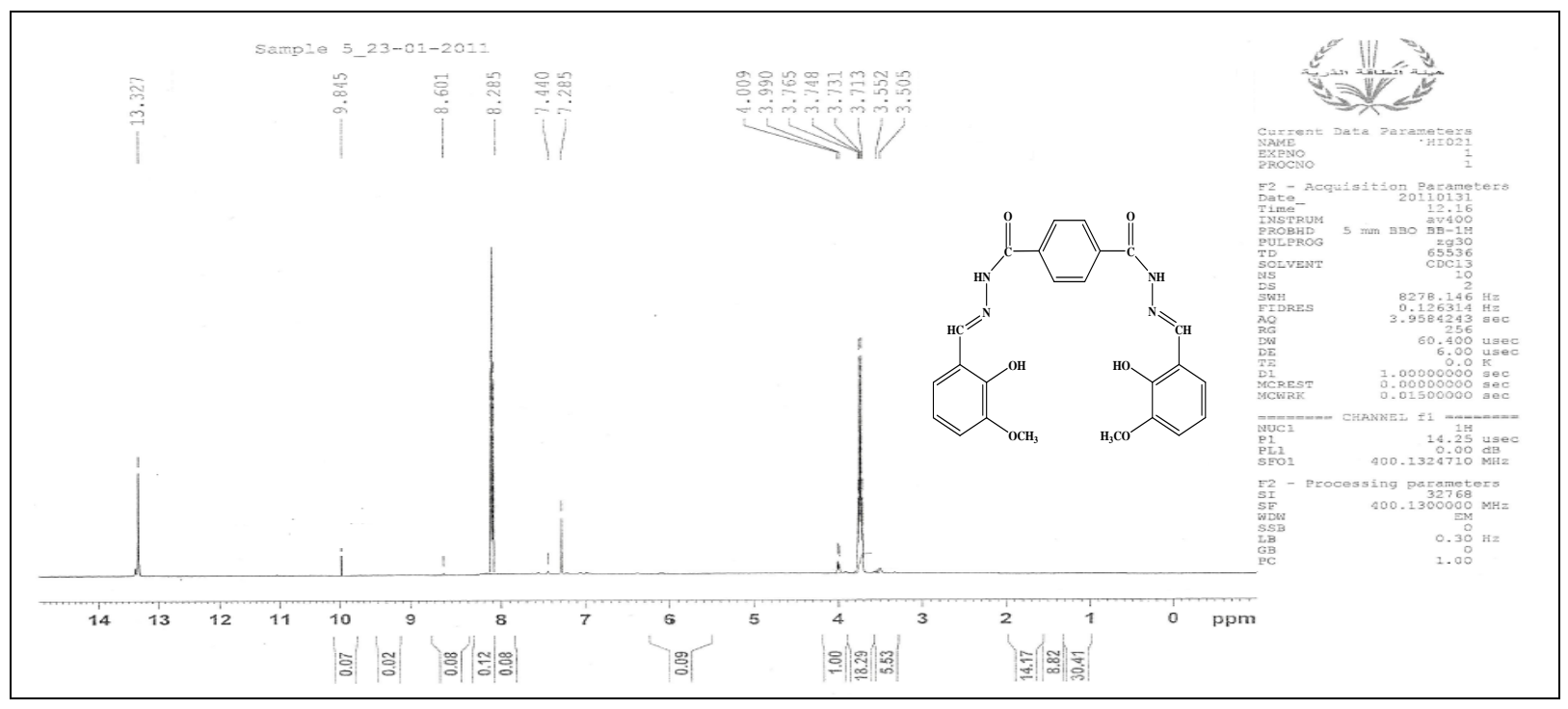

Fig.6. ${ }^{1} \mathrm{H}$ NMR spectrum of Schiff base(III) 


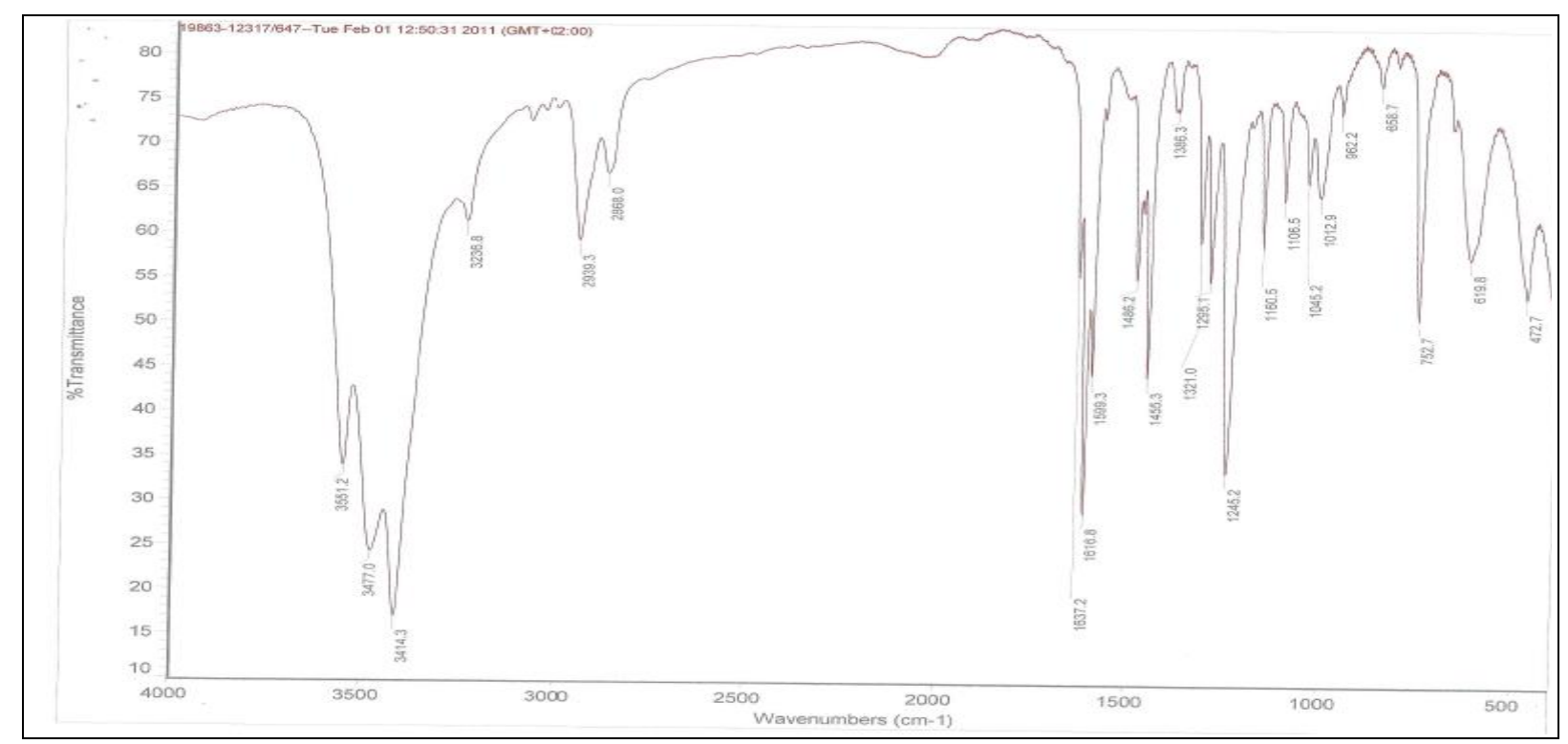

Fig.7. IR spectrum of Schiff base(IV)

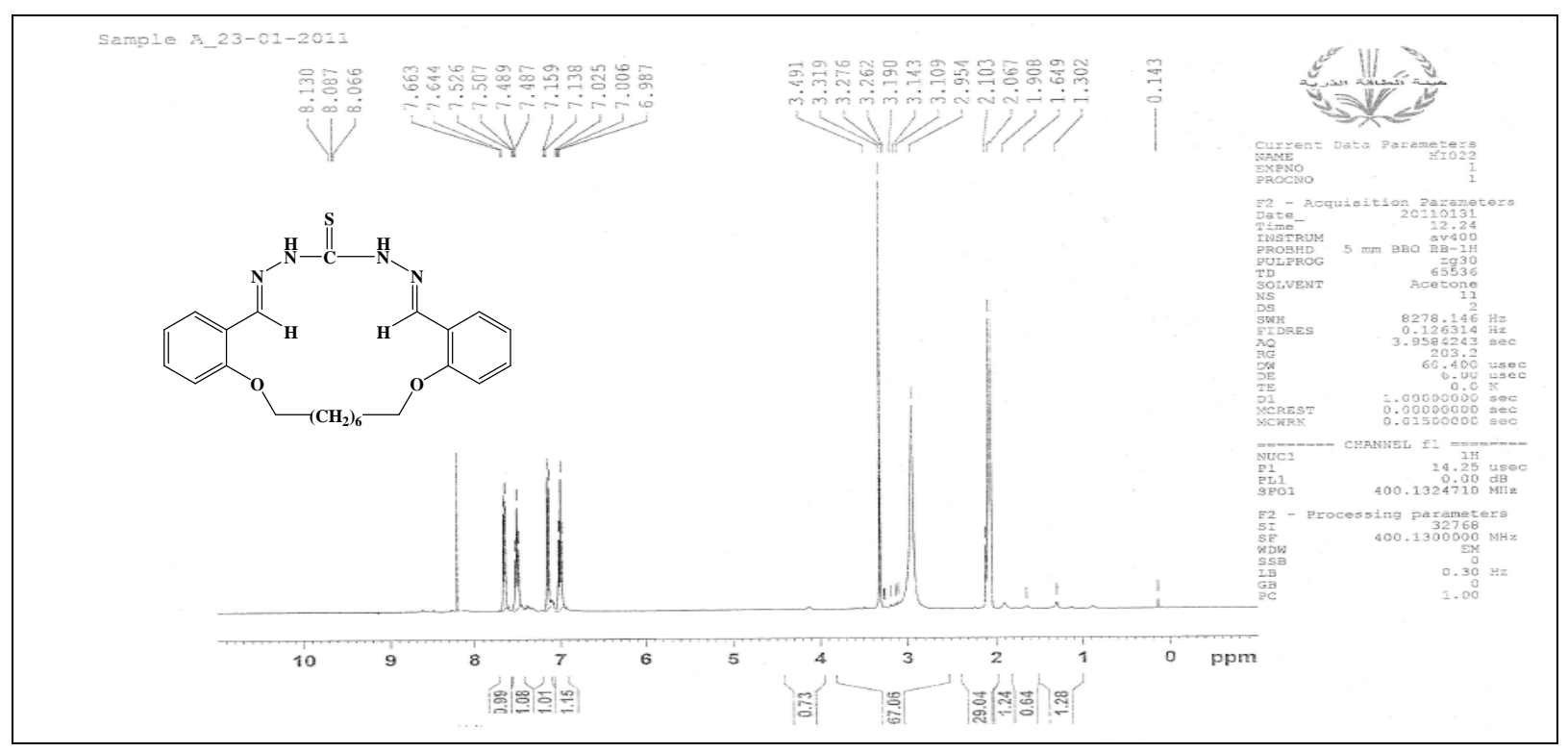

Fig.8. ${ }^{1} \mathrm{H}$ NMR spectrum of Schiff base(IV)

\subsection{ANTIBACTERIAL ACTIVITY}

During the last two or three decades, attention has been increasingly paid to the synthesis of Schiff bases Ligands which exhibits various antibacterial activities including antibacteria, fungicidal, tuberculostatic and plant growth regulative properties $[21,22]$. It was judicious to investigate the synthesis of various new types of Schiff bases and studied their antibacterial activity against four strains of bacteria (klebcella, Escherischa coli, Staphylococcus aureus, Salmonella typhimurium). The concentration used for the screened compounds is $1000 \mu \mathrm{g} / \mathrm{ml}$. Control discs were preformed using DMSO solvent and inhibition zones are measured in $\mathrm{mm}$. The results of antibacterial activity were compared with $25 \mu \mathrm{g} / \mathrm{ml}$ Ampcilline [23]. The results of the antibacterial activity are summarized in Table (4). 
TABLE 4: EFFECT OF THE LigANDS(I,II,III,IV) ON THE GROWTH OF BACTERIA (ZONE OF INHIBITION IN MM)

\begin{tabular}{|c|c|c|c|c|}
\hline \multirow{2}{*}{$\begin{array}{c}\text { Ligand } \\
(1000 \mu \mathrm{g} / \mathrm{ml})\end{array}$} & \multicolumn{3}{|c|}{ Bacteria } \\
\cline { 2 - 5 } & Escherichia coli & Salmonella typhi & klebcella & Staphyllococcus aureus \\
\cline { 2 - 5 } & + & + & + & ++ \\
\hline I & ++ & ++ & + & +++ \\
\hline II & + & + & - & +++ \\
\hline III & - & - & + & ++ \\
\hline IV & + & + & + & + \\
\hline $\begin{array}{l}\text { Ampicillin } \\
(25 \mu \mathrm{gl} / \mathrm{ml})\end{array}$ & & + & + & + \\
\hline
\end{tabular}

(-)No zones of inhibition were observed. Moderately sensitive,(+)Inhibition zones of 7-10mm. Sensitive,(++)Inhibition zones of $11-14 \mathrm{~mm}$. High sensitive,(+++)Inhibition zones of $15-20 \mathrm{~mm}$.

The ligands(I,III) show moderate activity against the gram-negative bacteria,except (II) against Escherichia coli , Salmonella typhi is high. Also, the Ligands(I,IV) show moderate a ctivity against the gram- positive bacteria,except (II,III) against Staphyllococcus aureus is high.

The ligand (IV) does not have significant activity against the gram-negative bacteria.

\section{CONCLUSION}

The compounds are new and are prepared for the first time. Also were characterization by 1H-NMR,IR,LC-MS spectral methods. Some the prepared ligands have been antibacterially screened i.e. studying their effects against gram-positive, three gram-negative bacteria. The results show that their activities were found to vary from moderate to very strong.

\section{REFERENCES}

[1] Abu-Hussen, A. A. Synthesis, spectroscopic, thermal, and antibacterial activities on solvatochromic mixed ligand copper(II) complexes. Coord. Chem. 59, 157. 2006.

[2] Sithambaram Karthikeyan, M.; Jagadesh Prasad, D.; Poojary, B.; Subramanya Bhat, K,Synthesis and antimicrobial activity of new Schiff bases containing coumarin moiety and their spectral characterization. Med. Chem. 14, 7482, 2006.
[3] Singh, K.; Barwa, M. S.; Synthesis and characterization of cobalt(II), nickel(II), copper(II) and zinc(II) complexes with Schiff base derived from 4-amino-3-mercapto-6-methyl-5-oxo-1,2,4triazine,Tyagi, P. Eur. J. Med. Chem., 41, 1. 2006.

[4] Pannerselvam, P.; Nair, R. R.; Vijayalakshmi, G.; Subramanian, E. H.; Sridhar,S. K. Synthesis of Schiff bases of 4-(4-aminophenyl)-morpholine as potential antimicrobial agents. Eur. J. Med. Chem., 40, 225, 2005.

[5] Sridhar, S. K.; Saravan, M.; Ramesh, A. Synthesis and antibacterial screening of hydrazones, Schiff and Mannich bases of isatin derivatives Eur. J. Med. Chem., 36, 615, 2001.

[6] Pandeya, S. N.; Sriram, D.; Nath, G.; Declercq, E, Synthesis of 3-[(Z)-2-piperazin-1-ylethylimino]-1,3-dihydro indol-2-one as a novel Schiff base Eur. J. Pharmacol, 9, 25, 1999.

[7] Mladenova, R.; Ignatova, M.; Manolova, N.; Petrova, T.; Rashkov, I. Synthesis, Structural Features and Evaluation of Antibacterial Activities of Two Schiff Bases Derived from 3,4Dihydroxybenzhydrazide Eur. Polym. J., 38, 989, 2002.

[8] Walsh, O. M.; Meegan, M. J.; Prendergast, R. M.; Nakib, T. A ChemInform Abstract: Synthesis of 3-Acetoxyazetidin-2-ones and 3-Hydroxyazetidin2-ones with Antifungal and Antibacterial Activity.. Eur. J. Med. Chem.,31, 989, 1996.

[9] Arora, K.; Sharma, K. P. Synth. React. Inorg. Met.-Org. Chem., 32, 913, 2003. 
[10] Vigato, P. A.; Tamburini, S. Coord Mononuclear and polynuclear complexes with a side-off compartmental Schiff base. Chem. Rev. 2004, 248, 1717. 11. Katsuki, T. Coord. Chem. Rev.,140, 189, 1995.

[11] Thangadurai, T. D.; Gowri, M.; Natarajan, K. Synthesis and characterization of new Schiff bases containing pyridine moiety and their derivatives as antioxidant agents Synth. React. Inorg. Met.Org. Chem.,32, 329, 2002.

[12] Ramesh, R.; Sivagamasundari, M, Synthesis, characterization, redox property and antibacterial activity of $\mathrm{Ru}(\mathrm{II})$ carbonyl complexes containing $\mathrm{O}, \mathrm{N}$-donor ligands and heterocyclic bases. React. Inorg. Met.-Org. Chem.,33, 899, 2003.

[13] Schonberg, A.; Latif, N. Antibacterial Actions and Metabolic Transformations of Furanocoumarins,J. Am. Chem. Soc.,76, 6208, 1954.

[14] Singer, L. A.; Kong, N. P. $\beta$-Acylvinyl intermolecularadical additions to double bonds: Stereoselective synthesis of functionalised (E)- $\alpha, \beta$ unsaturated carboxylic acids J. Am. Chem. Soc.,88, 5213, 1966.

[15] Prakash G.A.; Vinod K.B.; Sangamesh A.P.;N. Shivananda D, Synthesis, spectral characterization, in-vitro microantibacterial evaluation and cytotoxic activities of novel macrocyclic bis hydrazone, European Journal of Medicinal Chemistry 44 3552-3559, 2009.

[16] SALIH I., HAMDI T., The synthesis and spectral studies of macrocyclic $\mathrm{Cu}(\mathrm{II}), \mathrm{Ni}(\mathrm{II})$ complex, Journal chemistry, 6 (2), 227-284, 2008.

[17] Ferrari M.B., Capacchi S., G., Pelosi P. Tarasconi, R. Alberitini, S. Pineli, P. Lunghi, Octahedral $\mathrm{Co}(\mathrm{II})$ and $\mathrm{Ni}(\mathrm{II})$ complexes of Schiff bases, semicarbazone and thiosemi-carbazone, synthesis, antibacterial, spectral, and thermal studies, Inorg. Chim. Acta 286,134, 1999.

[18] Chohan Z.H., Sheazi S.K.A., Synthesis, characterization and thermal analysis of $\mathrm{Hg}(\mathrm{II})$ complexes with hydrazide ligands Synth. React. Inorg. Met.-Org. Chem. 29 , 105, 1999.

[19] Zainab T I.; 1993-reparation and study of the estimation of Platinum(II) and palladium(II) Spectro- photometrically AS Complexes With the Reagent 4,6-dihydroxy-2-mercapto pyrimidine, Master of Science in Chemistry, Kufa University.

[20] Ibrahim.U.H.; Basaran.I.; Kilic.T.; Cakir.U.; Synthesis, Complexation and Anti-
fungal,Antibacterial Activity Studies of a New Macrocyclic Schiff Base ,J. Hetrocyclic Chem.,43,1679, 2006.

[21] R.RAmin, A.T.Al-Subaie, B.A.El-Gamal, A.M.Mahasneh and I.S.Al-Naimi; Journal of the Medical Research Institute,22(1),1 (2001).

[22] Mohammad,R. G., Mehdi,T., Farnoush, F., Siavash,R., Parviz,N., and Masoud S. , Interaction Study of a new Bis-Bidentate Schiff's Base with some Metal Ions and its Application in Fabrication of Sm(III) Potentiometric Membrane Sensor .,Int. J. Electrochem. Sci., 3 .1559 - 1573, 2008.

[23] Ahmad .R, Ehsan. Z, Masoud. S.;2007, Effect of anionic surfactant on transport of copper(II) through liquid membrane containing a new synthesis Schiff base, Separation and Purification Technology 54 ,28-33,2007. 


\section{تحضير ودراسة خواض قواعد شيف مفتوحة وحلقية ضخمة جديدة ودراسة فعاليتها الحيوية}

$$
\text { قسم الكيمياء، كلية العلوم جامعة دمشق، سوريا فلاح }
$$

الملخص:

يركز هذا البحث على اصطناع أسس شيف مفتوحة جديدة تم تحضير ها من تكاثف الساليسل الدهيد مع كلٍ من ثنائي امينو ثنائي فينيل الميتان،وثنائي امينو ثنائي فينيل سلفيد، ومن تكاثف الاورثو فانيلين مع ثنائي ايتيل استر لحمض التيرفتاليك، وايضاً من حضر اساس شيف حلقي ضخم من تكاتف 6,1- ثنائي برومو حلقي الهكسان مع ثيوكربو هيدر ازيد. وشُخصت هذه المركبات بالتقنيات الطيفية المختلفة (LC-MS, 1H-NMR, IR) . كما دُرست الفعالية البكتيرية لهذه المركبات المصنعة. 